\title{
ELLIPSOMETRY OF THIN FILMS ON VAPOR-LIQUID INTERFACES
}

\author{
J.W. Schmidt and M.R. Moldover \\ National Bureau of Standards, Washington, D.C. 20234, U.S.A.
}

\begin{abstract}
Résumé - Dans certaines solutions binaires, la phase inférieure des deux phases liquides peut former une couche qui s'immisce entre la phase liquide supérieure et la vapeur. Nous trouvons qu'une telle couche se forme au dessus des solutions composées par un fluorocarbone $\left(\mathrm{C}_{7} \mathrm{~F}_{14}\right)$ et par un alcool $\left(i-\mathrm{C}_{3} \mathrm{H}_{7} \mathrm{OH}\right)$. Lorsque la température augmente, la couche apparaît brutalement à une température de mouillage $\mathrm{T}_{\mathbf{w}}=31 \mathrm{lK}$. Cette température est bien en-dessous de la température de solubilisation $\left(T_{C}=363 \mathrm{~K}\right)$. Au dessous de $T_{W}$, l'épaisseur de la couche (mesurêe par ellipsométrie) peut être nulle et n'est pas plus grande que $2 \mathrm{~nm}$. Au dessus de $\mathrm{T}_{\mathrm{w}}$ l'épaisseur de la couche est de plusieurs centaines d'Angstroems et sa variation avec la température est extrêmement faible. Lorsque la température d'un échantillon particulier a été augmentée jusqu'à un certain niveau vers $T_{C}$, la phase inférieure s'est dissoute dans la phase supérieure. A $328 \mathrm{~K}$ la phase inférieure a disparu. Au voisinage $( \pm 0,05 \mathrm{~K})$ de cette température l'épaisseur du film s'est annulée brutalement. Ces données expérimentales montrent clairement que les deux transitions sont du premier ordre.
\end{abstract}

Abstract - In certain binary solutions the lower of the two liquid phases can form a layer which intrudes between the upper liquid phase and the vapor. We find that such a layer does form above binary solutions of a fluorocarbon $\left(\mathrm{C}_{7} \mathrm{~F}_{14}\right)$ and an alcohol $\left(i-\mathrm{C}_{3} \mathrm{H}_{7} \mathrm{OH}\right)$. As the temperature is increased, the intruding layer abruptly appears at a characteristic wetting temperature $\mathrm{T}_{\mathrm{W}}=311 \mathrm{~K}$. This temperature is well below the consolute temperature $\left(\mathrm{T}_{\mathrm{C}}=363 \mathrm{~K}\right)$. Below $T_{w}$, the layer's thickness (measured by ellipsometry) may be zero and is no greacer than $2 \mathrm{~nm}$. Above $\mathrm{T}_{\mathrm{w}}$ the intruding layer's thickness is several hundred Angstroms and its variation with temperature is extremely weak.

As the temperature of a particular sample was raised still further towards $T_{C}$ the lower phase dissolved into the upper liquid phase. At $328 \mathrm{~K}$ the lower phase disappeared. Within $+0.05 \mathrm{~K}$ of this temperature the film thickness abruptly returned to zero. These data provide strong experimental evidence that both transitions are first order.

In a paper by Cahn [1], it was emphasized that when two fluid phases are brought near a critical point, one of the fluid phases will completely wet the other fluid phase and any third phase that happens to be present. This conclusion was based on the Van der Wals theory of interfaces and thus it should be fairly general. Recent experiments in mixtures of organic [2-7] and metallic [8,9] liquids can be interpreted as demonstrating that one of two critical phases wets the other critical phase and a non critical phase. In many binary mixtures the more dense phase can form a film on the surface of the less dense phase, thereby lowering the surface energy $[2,6,7]$. In a perfluoromethylcyclohexane-isopropanol mixture a film will form if the temperature is above a characteristic temperature $T_{w}=38^{\circ} \mathrm{C}$. The film thickness was measured and found to be several hundred Angstroms for $T>T_{w}$, with little temperature dependence. As the temperature is lowered below $T_{w}$ the film contracts abruptly to form a pendent lens bounded by a line of three phase contact. This abrupt change in thickness at $\mathrm{T}_{\mathrm{w}}$, as well as a linear dependence of $\cos \theta$ on temperature for $\mathrm{T}<\mathrm{T}_{\mathrm{W}}$ (where $\theta$ is one of the contact angles) firmly establishes the first-order character of this transition in the $\mathrm{C}_{7} \mathrm{~F}_{14}-\mathrm{iC}_{3} \mathrm{H}_{7} \mathrm{OH}$ system. 
Several theories which use long-ranged interatomic potentials predict a first-order transition provided that the range of the potential between unlike species is longer than the range of the potentials between like species [10].

In one sample, the isopropanol and fluorocarbon concentrations were chosen so that the two liquid phases became one isopropanol rich phase for $\mathrm{T}>55 \mathrm{C}$. Three temperature regions were clearly marked in this sample (Fig. 1.); (i) below $T_{W}$, the film thickness was essentially zero within the resolution of the apparatus $+10 \AA ;$ (ii) above $T_{W}$ but below 55C the film thickness was $410 \pm 15 \AA$; and (iii) for $T$ above $55 \mathrm{C}$, the film thickness was again zero. No precursors to the wetting transition at $\mathrm{T}_{\mathrm{W}}$ were detected on either side of $\mathrm{T}_{\mathrm{W}}$, nor were any precursors detected at $\mathrm{T}=55 \mathrm{C}$.

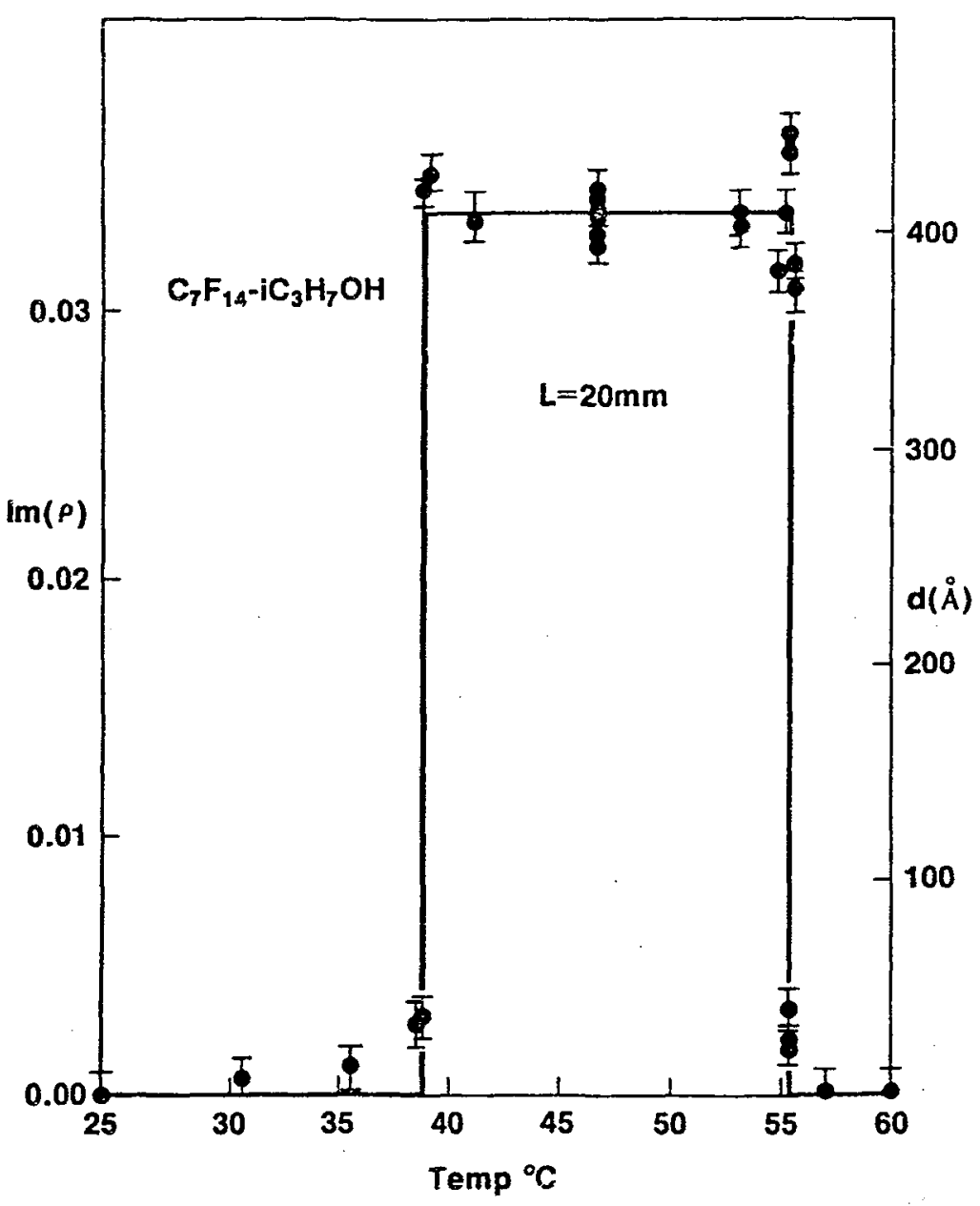

Fig. 1 - The imaginary part of the complex reflectivity ratio ( $\rho$ ) of the vaporliquid interface as a function of temperature. 
In order to achieve stable films, efforts were made to eliminate thermal gradients as far as possible. A three stage thermostat was used in which the outer two stages were actively controlled, while the inner stage was passive. Daily temperature fluctuations were kept below $0.5 \mathrm{mk}$. Since the thermal time constant for the inner she11 was approximately 100 minutes, this meant that the maximum rate of temperature change was $₹ 5 \mu \mathrm{K} /$ minute. The incident light intensity from the ellipsometer's laser was kept below $0.1 \mathrm{~m}$ watt and blocked off when not recording data.

Film thicknesses were measured using a manual null ellipsometer with the arrangement : laser, neutral density filter, polarizer (fixed at 9.5 deg.), quarter wave plate, surface under study, analyzer. The quarter wave plate and analyzer were adjusted for extinction and their orientations were noted. The incident angle was fixed at about $59 \mathrm{deg}$. Carbon tetra chloride was used in the optical cell as a calibrating fluid [1].

In addition we have made differential measurements of the bulk index of refraction of alcohol rich phase above and below 55C. The index of refraction was measured and the temperature was lowered automatically at a slow rate ( $23 \mathrm{mK} /$ hours). The temperature at which bulk phase separation occurred was located with a precesion of $\pm 0.03 \mathrm{C}$ by noting the discontinuity in $\frac{\mathrm{dn}}{\mathrm{d} T}$.

By monitoring film thickness in the same sample and same apparatus we could establish the temperature at which: 1 . the film formed at the vapor liquid interface and 2 . bulk phase separation occurred. These two events happened at the same temperature $(+.05 \mathrm{C}-0.00 \mathrm{C})$.

Thus we have established an upper bound at this temperature $(55 \mathrm{C})$ on the difference in temperature between the appearance of the surface film and bulk phase separation.

\section{References}

1. Cahn, (J. W.), J. Chem. Phys. (1977), 66, 3667.

2. Moldover, (M. R.), and Cahn, (J.W.), Science 1980, 207, 1073.

3. Beysens, (D.) and Leibler, (S.), J. Physique Lettres 1982, 43, L-133.

4. Frank, (C.), and Schnatterly, (S.E.), Phys. Rev. Letters 1982, $26,763$.

5. Poh1, (D.W.) and Goldberg, (W.I.), Phys. Rev. Letters 1982, 48, 1111.

6. Kwon, (O'D.), Beaglehole, (D.), Webb, (W.W.), Widom, (B.), Schmidt, (J.W.), Cahn, (J.W.), Moldover, (M.R.), and Stephenson, (B.), Phys. Rev. Letters 1982, $48,185$.

7. Schmidt, (J.W.) and Moldover, (M.R.), J. Chem. Phys, to be published.

8. Grugel, (R.N.) and Hellawe11, (A.), Metallurgical Transitions A1981, 12 A, 669.

9. Perepezko, (J.H.), Galaup, (C.), and Cooper, (K.P.), "Solidification of Undercooled Monotectic Alloys," in Proceedings of the Materials Research Society Symposium: Materials Processing Research in the Reduced Gravity Environment of Space, ediled by G.E. Rindone (North Holland, N.Y.) 1982.

10. Taranzona (P.), Telo da Gama (M.M.), Evans, (R.) Molecular Physics (to be published).

11. Beaglehole, (D.), Physica, (1980), 100B, 163 . 